\title{
PENGEMBANGAN MEDIA PEMBELAJARAN KETERAMPILAN MENYIMAK DAN MEMBACA BERBASIS MULTIMEDIA INTERAKTIF SISWA KELAS IV SEKOLAH DASAR
}

\author{
Endang Sri Maruti \\ Prodi PGSD FIP IKIP PGRI MADIUN
}

\begin{abstract}
This research aims to develop interactive multimedia-based instructional media in order to improve students' listening and reading skills. This research refers to the development of 4-D method. 33 test subjects as children. Validation of research instruments are sheets, observation sheets, questionnaires, and learning tests. Data collection techniques used validation and observation techniques. Techniques of data analysis used qualitative descriptive data. Lesson plan results demonstrate feasibility can be trusted with a good reliability of the instrument category. The observation of student activity meets the criteria specified limits effectiveness. Based on the questionnaire responses of students, learning with interactive $C D$ was interesting. Student learning outcomes showed positive development. Thus, the products developed have been effective.
\end{abstract}

Key words: development, instructional media, listening skills, reading skills, interactive multimedia

\begin{abstract}
Abstrak:
Penelitian ini bertujuan untuk mengembangkan media pembelajaran berbasis multimedia interaktif guna meningkatkan kemampuan menyimak dan membaca siswa. Penelitian pengembangan ini merujuk pada metode 4-D. Subjek uji coba sebanyak 33 anak. Instrumen penelitian berupa lembar validasi, lembar pengamatan, angket, dan tes belajar. Teknik pengumpulan data dengan teknik validasi dan observasi. Teknik analisis data secara deskriptif kualitatif. Hasil keterlaksanaan RPP menunjukkan dapat dipercaya dengan reliabilitas instrumen berkategori baik. Hasil pengamatan aktivitas siswa telah memenuhi kriteria batas efektivitas yang ditentukan. Berdasarkan angket respons siswa, pembelajaran dengan $\mathrm{CD}$ interaktif adalah menarik. Hasil belajar siswa menunjukkan perkembangan positif. Dengan demikian, produk yang dikembangkan telah efektif.
\end{abstract}

Kata Kunci: pengembangan, media pembelajaran, keterampilan menyimak, keterampilan membaca, multimedia interaktif 


\section{A. Pendahuluan}

Berdasarkan

hasil

pengamatan dan wawancara dengan guru bahasa Indonesia, selama ini di SDN 01 Turi, guru masih mengalami banyak kendala dalam pemberian materi walaupun bahasa Indonesia adalah bahasa sehari-hari. Penyebabnya antara lain guru masih sangat bergantung pada buku teks, cara mengajar yang konvensional, dan tidak digunakannya media pembelajaran.

Secara umum, media pembelajaran berguna untuk mengatasi berbagai hambatan. Misalnya hambatan komunikasi, keterbatasan ruang kelas, kepasifan siswa, pengamatan siswa yang kurang seragam, tempat belajar yang terpencil, dan sebagainya. Untuk itulah, guru perlu menggunakan media pembelajaran sebagai alat bantu dalam proses belajar mengajar.

Anak usia sekolah dasar memiliki tiga ciri belajar, yaitu (1) konkret, (2) integratif, (3) hierarkis (Depdiknas, 2003). Proses belajar siswa sekolah dasar bermula dari hal-hal yang konkret, yakni yang dapat dilihat, diraba, dan didengar. Pada tahap usia sekolah dasar, anak memandang sesuatu yang dipelajari sebagai suatu keutuhan karena anak belum mampu memilah-milah konsep dari berbagai disiplin ilmu. Selain itu, cara belajar anak sekolah dasar dilakukan secara bertahap, mulai dari hal yang sederhana ke hal yang kompleks. Tiga hal ini juga berlaku pada pembelajaran bahasa di sekolah.

Pembelajaran bahasa memiliki proses yang berbeda dengan pemerolehan bahasa (Yulianto, 2011:24). Pembelajaran bahasa pada siswa yang ditransformasikan oleh guru meliputi empat aspek yaitu menyimak, berbicara, membaca, dan menulis. Keempat aspek itu diserahkan kepada guru sepenuhnya. Oleh karena itu, sebagai guru harus sudah mampu berpikir kritis dan inovatif dalam mencari metode serta bahan ajar yang akan disampaikan kepada peserta didik atau anak didik sesuai dengan tahap perkembangannya.

Penelitian ini hanya berkutat pada keterampilan berbahasa yang aktif reseptif, yaitu keterampilan menyimak dan membaca. Kemampuan berbahasa yang aktif reseptif pada hakikatnya merupakan kemampuan atau proses decoding, kemampuan untuk bahasa yang dituturkan oleh pihak lain (Nurjamal, 2011:131). Pemahaman terhadap bahasa yang dituturkan oleh pihak lain tersebut dapat melalui sarana bunyi atau sarana tulisan. Sarana itulah yang akan dikembangkan menjadi media pembelajaran.

Media pembelajaran adalah sebuah alat yang berfungsi dan digunakan untuk menyampaikan pesan pembelajaran (Sanaky, 2011:65). Menurut Sutjipto (2011:76), media pembelajaran adalah alat yang dapat membantu proses belajar mengajar dan berfungsi untuk memperjelas makna pesan yang disampaikan, sehingga dapat mencapai 
tujuan pembelajaran dengan lebih baik dan sempurna.

Salah satu jenis media pembelajaran adalah multimedia interaktif. Multimedia merupakan perpaduan antara berbagai media (format file) yang berupa teks, gambar (vektor atau bitmap), suara, animasi, video, interaksi, dan lainlain yang telah dikemas menajdi file digital (komputerisasi), yang digunakan untuk menyampaikan pesan. Sedangkan interaktif, terkait dengan komunikasi dua arah atau lebih komponen-komponen komunikasi. Komponen komunikasi dalam multimedia interaktif (berbasis komputer) adalah hubungan antara manusia (sebagai user/ pengguna produk) dan computer (software/ aplikasi/ produk dalam format file tertentu, biasanya dalam bentuk CD). Berdasarkan pengertian multimedia dan interaktif tersebut, maka multimedia interaktif adalah suatu tampilan multimedia yang dirancang oleh desainer agar tampilannya memenuhi fungsi menginformasikan pesan dan memiliki interaktivitas kepada penggunanya (user) (Munir, 2012:110).

Keefektifan penggunaan media, dalam hal ini adalah multimedia interaktif dapat dilihat dari empat aspek, yaitu keterlaksanaan RPP, aktivitas siswa, respons siswa, dan hasil tes belajar siswa. RPP dijabarkan dari silabus untuk mengarahkan kegiatan belajar siswa dalam upaya mencapai kompetensi dasar. RPP untuk setiap KD dapat dilaksanakan dalam satu kali pertemuan atau lebih (Lestari, 2013:35). Keaktifan siswa tentu juga dipengaruhi oleh guru dalam memberikan pembelajaran. Respons siswa merupakan gambaran reaksi yang muncul dari pembelajaran yang dilakukan oleh guru (Usman, 2004:26). Tes hasil belajar, karena tes yang diberikan pada akhir pembelajaran untuk menilai hasil pelajaran dari materi yang telah diberikan (Purwanto, 2012:155).

Berdasarkan hal-hal di atas, penelitian ini berupaya mengembangkan media pembelajaran untuk meningkatkan kemampuan menyimak dan membaca. Selain itu untuk membantu guru meningkatkan suasana belajar yang menyenangkan dan menarik bagi siswa, terutama dalam keterampilan menyimak dan membaca, maka peneliti menggunakan media pembelajaran berbasis multimedia interaktif, dalam bentuk CD interaktif. Di dalam CD interaktif tersebut, termuat materi pelajaran, latihan soal, dan juga rangkuman materi, termasuk silabus. Tampilan di dalam CD interaktif dibuat semenarik mungkin, dengan desain warna, gambar, animasi, teks, dan video.

Fokus penelitian ini adalah untuk mengembangkan media pembelajaran keterampilan menyimak dan membaca berbasis multimedia interaktif siswa kelas IV Semester Genap. Media tersebut kemudian diuji cobakan untuk melihat keefektifannya. keefektifan penggunaan 
media itu dapat dilihat dari keterlaksanaan RPP, aktivitas siswa, respons siswa, dan hasil belajar siswa kelas IV semester genap setelah mendapat pembelajaran dengan menggunakan media pembelajaran keterampilan menyimak dan membaca berbasis multimedia interaktif.

\section{B. Metode Penelitian}

Penelitian pengembangan ini termasuk dalam penelitian deskriptif kualitatif dengan rancangan pengembangan model 4-D. Data penelitian diperoleh dari beberapa sumber data, di antaranya:

(1) Siswa yang mengikuti pembelajaran Bahasa Indonesia tahun pembelajaran 2014/2015, untuk uji coba I dan uji coba II dilaksanakan pada siswa kelas IV SDN 01 Turi semester genap tahun pembelajaran 2014/2015 dengan jumlah siswa 33 orang; (2) validator ahli materi dan ahli media pembelajaran bahasa Indonesia. Adapun yang bertindak sebagai validator ahli materi pembelajaran Bahasa Indonesia ialah Bapak Dr. Suyatno, M.Pd, dan validator ahli media pembelajaran ialah Bapak Dr. H. Bachtiar S. Bachri, M.Pd. Pengumpulan data dilakukan dengan teknik validasi dan observasi. Analisis data dilakukan dengan cara deskriptif kualitatif.

\section{Hasil Penelitian}

Sesuai dengan rumusan masalah, penelitian ini telah menghasilkan tiga hal, yaitu (1) proses pengembangan media, (2) kualitas media, dan (3) keefektifan penggunaan media pembelajaran keterampilan menyimak dan membaca berbasis multimedia interaktif siswa kelas IV Semester Genap.

\section{Proses Pengembangan Media Pembelajaran Berbasis Multimedia Interaktif}

Model pengembangan media pembelajaran yang digunakan dalam penelitian ini yaitu 4-D yang terdiri dari pendefinisian, perencanaan, pengembangan, dan penyebaran. Pada penelitian ini, peneliti hanya melakukan tahap tersebut hanya sampai pada tahap pengembangan saja. Tahap penyebaran tidak dilaksanakan dalam penelitian ini karena secara otomatis hasil dari penelitian ini nantinya digunakan secara massal di SDN 01 Turi.

Tahap pendefinisian meliputi (a) analisis awal akhir, (b) analisis siswa, (c) analisis tugas, dan (d) perumusan tujuan pembelajaran. Pada tahap analisis awal akhir ditemukan masalah mendasar dalam kegiatan pembelajaran Bahasa Indonesia untuk keterampilan menyimak dan membaca. Guru kesulitan mendapat media pembelajaran yang tepat untuk mengajarkan kedua keterampilan tersebut. Untuk itulah penelitian ini diadakan supaya dapat mengatasi permasalahan tersebut.

Pada tahap analisis siswa, diketahui jumlah siswa di kelas IV SDN 01 Turi berjumlah 33 orang, 18 laki-laki 
dan 15 perempuan. Kondisi siswa yang terbiasa dengan komputer, membuat pembelajaran yang menggunakan media berbasis multimedia interaktif menjadi tidak terlalu asing dan kaku. Walaupun masih ada beberapa siswa yang merasa asing dan kebingungan. Namun kendala tersebut dapat segera diatasi karena guru menerapkan sistem pengawasan yang bagus.

Dalam tahap analisis tugas, ada dua hal yang dilakukan, yaitu analisis struktur kurikulum dan analisis prosedural. Berdasarkan analisis struktur kurikulum, Standar Kompetensi (SK) yang biasa digunakan pada Kurikulum Tingkat Satuan Pendidikan (KTSP) diubah menjadi Kompetensi Inti (KI) pada Kurikulum 2013. Berdasarkan analisis prosedural, dalam kegiatan belajar mengajar digunakan media pembelajaran berbasis multimedia interaktif, materi pembelajaran yang dimuat dalam CD interaktif. Tahap yang terakhir dalam tahap pendefinisian adalah tahap perumusan tujuan pembelajaran. Dalam tahap perumusan tujuan pembelajaran, ada sebelas tujuan yang harus dicapai siswa setelah pembelajaran. Kesebelas tujuan tersebut masing-masing telah menunjukkan kemampuan siswa dari C1 sampai dengan C6.

Tahap kedua pada penelitian ini adalah tahap perencanaan. Ada dua tahap yang dilakukan dalam tahap perencanaan, yaitu tahap perencanaan media ajar yang kemudian dilanjutkan dengan tahap perencanaan perangkat ajar pendukung lainnya. Pada tahap perencanaan media, pembuatan prototype media pembelajaran berbasis multimedia interaktif harus dimatangkan. Adapaun langkah-langkah yang dilakukan yaitu pembuatan garis besar media, pembuatan flowchart, pembuatan storyboard, dan pengumpulan bahanbahan yang dibutuhkan. Selanjutnya, pada tahap perencanaan perangkat pembelajaran pendukung lainnya juga sudah harus dimatangkan. Adapun perangkat pembelajaran pendukung yang dikembangkan dalam penelitian ini berupa silabus, RPP, dan THB.

Tahap terakhir pada penelitian ini adalah tahap pengembangan. Kegiatan yang dilakukan dalam tahap pengembangan yaitu validasi media pembelajaran berbasis multimedia interaktif dan validasi perangkat pembelajaran pendukung, uji coba terbatas, dan uji coba luas. Kegiatan pertama yang dilakukan pada tahap pengembangan adalah validasi media pembelajaran. Validasi media pembelajaran dilakukan pada dua validator, yaitu ahli materi dan ahli media pembelajaran Bahasa Indonesia. Masingmasing ahli diambil satu orang saja. Hal tersebut dilakukan karena satu orang ahli saja sudah cukup mewakili dan cukup representatif dalam memvalidasi. Kegiatan selanjutnya adalah validasi perangkat pembelajaran pendukung yang dilakukan oleh ahli pembelajaran Bahasa 
Indonesia dan guru yang mengajar bahasa Indonesia di sekolah yang bersangkutan.

Kegiatan kedua pada tahap pengembangan adalah uji coba terbatas. Uji coba terbatas dilakukan di kelas IV B dengan mengambil 10 siswa, dengan kegiatan pembelajaran Bahasa Indonesia menggunakan media pembelajaran berbasis multimedia interaktif. Uji coba terbatas dilakukan di kelas IV B karena kelas tersebut merupakan kelas yang paling rendah nilainya dibandingkan dengan kelas IV yang lain. Jumlah siswa yang diambil juga berdasarkan nilai, sepuluh siswa dengan nilai terendah. Berdasarkan hasil uji coba terbatas tersebut, nantinya dapat diketahui seberapa banyak kompetensi atau tujuan yang dapat dicapai dengan media pembelajaran yang dikembangkan.

Setelah mengetahui hasil uji coba terbatas, maka kegiatan terakhir yang dilaksanakan adalah kegiatan uji coba luas. Uji coba luas di lakukan di kelas IV dengan menyertakan seluruh siswa yang berjumlah 33 orang, dengan kegiatan pembelajaran Bahasa Indonesia menggunakan media pembelajaran berbasis multimedia interaktif.

\section{Kualitas Media Pembelajaran Berbasis Multimedia Interaktif dan Perangkat Pendukung}

Kualitas media pembelajaran berbasis multimedia interaktif dan perangkat pembelajaran pendukung lainnya dapat ditentukan dari hasil validasi. Validasi media pembelajaran dilakukan oleh ahli materi pembelajaran Bahasa Indonesia dan ahli media pembelajaran.

Validasi media berbasis multimedia interaktif dilakukan oleh ahli materi dan ahli media pembelajaran Bahasa Indonesia. Hasil angket penilaian ahli materi terhadap multimedia interaktif mata pelajaran Bahasa Indonesia materi wawancara menunjukkan ada tujuh komponen yang tidak perlu dilakukan revisi, sedangkan empat komponen sisanya harus direvisi terlebih dahulu sebelum diujicobakan. Tujuh komponen yang sudah layak dan tidak perlu revisi adalah: tujuan pembelajaran, relevansi tujuan pembelajaran dengan $\mathrm{KI} / \mathrm{KD}$, penggunaan strategi pembelajaran, hubungan materi dengan tujuan pembelajaran dalam multimedia interaktif, soal-soal latihan dan evaluasi dalam multimedia interaktif, struktur kalimat dalam multimedia interaktif, dan istilah yang digunakan dalam multimedia interaktif. Sedangkan empat sisanya masih kurang layak dan perlu perbaikan, yaitu materi pada multimedia interaktif kurang lengkap, materi dalam multimedia interaktif sulit dipahami, ejaan dalam multimedia interaktif banyak yang kurang tepat, dan penggunaan tata bahasa dalam multimedia interaktif yang kurang 
baku. Keempat saran dan masukan dari validator kemudian direvisi, dan hasil revisi dikembalikan lagi kepada validator untuk disetujui dan siap dipakai dalam proses pembelajaran di kelas.

Hasil angket penilaian ahli media terhadap multimedia interaktif mata pelajaran Bahasa Indonesia materi wawancara menunjukkan ada sembilan komponen yang tidak perlu dilakukan revisi, sedangkan enam komponen sisanya harus direvisi terlebih dahulu sebelum diuji cobakan. Kesembilan komponen yang tidak perlu direvisi karena: tujuan pembelajaran sudah efektif, multimedia interaktif pada aspek keterampilan menyimak dan membaca sudah sesuai, tampilan visual berupa teks, gambar, animasi, dan simulasi multimedia interaktif sudah jelas dan memenuhi ketepatan sasaran, animasi dan simulasi dalam multimedia interaktif menarik, penggunaan visual berupa teks, gambar, animasi, dan simulasi dalam multimedia interaktif sudah menarik, tampilan (teks, suara, gambar, animasi, dan simulasi) dalam multimedia interaktif sudah urut, pengoperasian termasuk simulasi multimedia interaktif cukup mudah, dan tampilan grafis animasi dan simulasi dalam multimedia interaktif sudah jelas. Keenam komponen lainnya perlu direvisi karena: tampilan audio yang berupa musik dan suara dalam multimedia interaktif belum memenuhi ketepatan sasaran, penggunaan audio berupa musik, dan suara dalam multimedia interaktif belum menarik, bentuk tulisan (huruf dan font) dalam multimedia interaktif kurang jelas, akses setiap lembar (frame) dalam multimedia interaktif cukup sulit, petunjuk penggunaan multimedia interaktif masih keliru, dan kualitas audio dan visual (gambar dan teks) dalam multimedia interaktif masih kurang bagus karena ada suara yang tidak jernih. Setelah keenam komponen tersebut direvisi, kemudian draf media dikembalikan lagi pada validator. Setelah mendapat persetujuan untuk diujicobakan, maka media pun siap untuk digunakan pada kelas uji coba.

Perangkat pembelajaran pendukung lainnya juga harus divalidasi terlebih dahulu oleh ahli. Hasil validasi RPP menunjukkan bahwa RPP memperoleh penilaian baik. Meskipun demikian, terdapat saran-saran perbaikan dari validator dan setelah direvisi, maka RPP tersebut layak dan dapat digunakan dalam kegiatan belajar mengajar pada siswa kelas IV SD.

Perangkat pembelajaran pendukung lainnya adalah Tes Hasil belajar (THB). Hasil validasi Tes Hasil Belajar (THB) siswa memperoleh predikat layak atau baik, namun tetap ada beberapa saran perbaikan dari validator seperti teks bacaan yang terlalu panjang, gambar yang kurang jelas, dan gambarnya lebih diperbanyak. Setelah direvisi, THB siap untuk diujicobakan. 


\section{Keefektifan}

Pembelajaran Multimedia Interaktif dan Perangkat Pendukung

Keefektifan media pembelajaran berbasis multimedia interaktif dan perangkat pembelajaran pendukung lainnya dapat dilihat dari empat kegiatan, yaitu pengamatan keterlaksanaan RPP, pengamatan aktivitas siswa, respons siswa, dan hasil belajara siswa.

Keterlaksanaan RPP pada kelas uji coba terbatas menunjukan bahwa RPP pada pertemuan 1, pertemuan 2 , dan pertemuan 3 adalah reliabel dan hasil pengamatan dari dua orang pengamat dapat dipercaya dengan reliabilitas instrumen berkategori baik. Berdasarkan hasil pengamatan aktivitas siswa pada kelas uji coba luas menunjukkan bahwa kategori aktivitas siswa seluruhnya memenuhi kriteria batas efektivitas yang ditentukan. Berdasarkan angket respons siswa, dapat dilihat bahwa cara guru dalam menyampaikan materi pembelajaran, materi pembelajaran yang terdapat dalam CD interaktif, dan metode yang pembelajaran yang digunakan dalam $\mathrm{CD}$ interaktif menarik bagi siswa.

Ukuran terakhir yang dapat menentukan keefektifan media pembelajaran berbasis multimedia interaktif dan perangkat pembelajaran pendukung lainnya adalah hasil tes belajar siswa. Tes belajar siswa dilakukan dua kali pada setiap kelas uji coba. Tes pertama pada uji coba terbatas dilakukan setelah pembelajaran tanpa penggunaan media pembelajaran berbasis multimedia interaktif. Tes pertama ini disebut dengan pretest. Hasil pretest di kelas uji coba terbatas, menunjukkan hanya 1 siswa yang tuntas dengan nilai 70. Sedangkan untuk ketuntasan secara klasikal adalah 10\% belum memenuhi nilai standar kriteria ketuntasan minimal yang ditetapkan. Pada hasil posttest dari 10 siswa, semuanya dinyatakan tuntas karena telah mencapai nilai standar ketuntasan minimal, bahkan nilai yang dicapai melebihi dari nilai standar kriteria ketuntasan minimal yang ditetapkan.

Hasil tes pada kelas uji coba luas menunjukkan bahwa hasil pretest dikelas uji coba luas terdapat dua siswa yang tuntas secara individu dengan nilai 70 . Sedangkan untuk ketuntasan secara klasikal adalah $6,1 \%$ belum memenuhi nilai standar kriteria ketuntasan minimal yang ditetapkan. Untuk hasil posttest dari 33 siswa yang ada, 28 siswa dinyatakan tuntas secara individu dan 5 siswa dinyatakan belum tuntas secara individu berdasarkan nilai yang diraih. Untuk ketuntasan secara klasikal rata-rata adalah $84,8 \%$, berdasarkan nilai standar ketuntasan minimal yang ditetapkan, maka hasil posttest dinyatakan tuntas.

Dilihat dari hasil belajar dengan dengan menggunakan media keterampilan menyimak dan membaca pembelajaran berbasis multimedia interaktif dengan model pembelajaran 
langsung maka hasilnya sangat positif. Siswa lebih antusias belajar karena menggunakan media pembelajaran dengan tampilan materi yang dikemas dalam CD interaktif dan menarik bagi mereka.

\section{Simpulan}

Dalam proses pengembangan media pembelajaran berbasis multimedia interaktif ada tiga tahap yang digunakan, yaitu pendefinisian, perencanaan, dan pengembangan.

Tahap

pendefinisian meliputi (a) analisis awal akhir, (b) analisis siswa, (c) analisis tugas, dan (d) perumusan tujuan pembelajaran. Tahap perencanaan terdiri dari tahap perencanaan media ajar dan tahap perencanaan perangkat ajar pendukung lainnya. Pada tahap pengembangan dilakukan validasi media pembelajaran berbasis multimedia interaktif dan validasi perangkat pembelajaran pendukung, uji coba terbatas, dan uji coba luas.

Kualitas media pembelajaran berbasis multimedia interaktif dan perangkat pembelajaran pendukung lainnya dapat ditentukan dari hasil validasi. Hasil angket penilaian ahli materi terhadap multimedia interaktif mata pelajaran bahasa Indonesia materi wawancara menunjukkan ada tujuh komponen yang tidak perlu dilakukan revisi, sedangkan empat komponen sisanya harus direvisi terlebih dahulu sebelum diujicobakan. Hasil angket penilaian ahli media terhadap multimedia interaktif mata pelajaran bahasa Indonesia materi wawancara menunjukkan ada sembilan komponen yang tidak perlu dilakukan revisi, sedangkan enam komponen sisanya harus direvisi terlebih dahulu sebelum diuji cobakan. Hasil validasi RPP menunjukkan bahwa RPP memperoleh penilaian baik dengan reliabilitas sebesar 3,7. Hasil validasi THB memperoleh predikat layak atau baik dengan reliabilitas sebesar 3,76.

Keefektifan media pembelajaran berbasis multimedia interaktif dan perangkat pembelajaran pendukung lainnya dapat dilihat dari empat kegiatan, yaitu pengamatan keterlaksanaan RPP, pengamatan aktivitas siswa, respons siswa, dan hasil belajar siswa. Keterlaksanaan RPP pada kelas uji coba terbatas menunjukkan bahwa RPP pada ketiga pertemuan adalah reliabel dan hasil pengamatan dari dua orang pengamat dapat dipercaya dengan reliabilitas instrumen berkategori baik. Hasil pengamatan aktivitas siswa pada kelas uji coba luas menunjukkan bahwa kategori aktivitas siswa seluruhnya memenuhi kriteria batas efektivitas yang ditentukan. Berdasarkan angket respons siswa, dapat dilihat bahwa cara guru dalam menyampaikan materi pembelajaran, materi pembelajaran yang terdapat dalam $\mathrm{CD}$ interaktif, dan metode yang pembelajaran yang digunakan dalam CD interaktif menarik bagi siswa. Tes belajar siswa dilakukan dua kali pada setiap kelas uji coba. Dilihat dari hasil 
belajar dengan menggunakan media keterampilan menyimak dan membaca pembelajaran berbasis multimedia interaktif dengan model pembelajaran langsung maka hasilnya sangat positif. Siswa lebih antusias belajar karena menggunakan media pembelajaran dengan tampilan materi yang dikemas dalam CD interaktif dan menarik bagi mereka. Berdasarkan keempat hal tersebut, maka media pembelajaran menyimak dan membaca berbasis multimedia interaktif ini telah efektif penggunaannya.

Berdasarkan hasil penelitian dan diskusi hasil penelitian, maka penelitian ini masih memiliki banyak kekurangan. Untuk itu masih perlu diadakan penelitian lanjutan dengan pengembangan media yang sama untuk kelas yang berbeda atau pada materi ajar yang lain.

\section{Daftar Pustaka}

Depdiknas. 2003. Kurikulum

Berbasis Kompetensi Standar

Kompetensi Mata Pelajaran

Bahasa Indonesia SD.

Jakarta: Depdiknas.

Lestari,I. 2013. Pengembangan Bahan Ajar Berbasis

Kompetensi.Padang:

Akademia Permata.

Munir. 2012. Multimedia, Konsep

dan Aplikasidalam

Pendidikan. Bandung:

Alfabeta.
Nurjamal, D., Sumirat, W., \& Darwis, R. 2011. Terampil Bahasa. Bandung: Alfabeta.

Purwanto, N. 2012. Prinsip-Prinsip dan

Teknik Evaluasi Pengajaran. Bandung: Remaja Rosdakarya.

Rusman. 2012. Belajar dan Pembelajaran Berbasis Komputer. Bandung: Alfabeta.

Sanaky, H. A. 2011. Media Pembelajaran. $\quad$ Yogyakarta: Kaukaba Dipantara.

Sutjipto, C. K. 2011. Media Pembelajaran :Manual dan Digital. Bogor: Ghalia Indonesia.

Yulianto, Bambang. 2011. Pengantar Teori Belajar Bahasa. Surabaya: Unesa University Press. 